\title{
VASES FROM CALYMNOS AND CARPATHOS.
}

\author{
[PL. LXXXIII.]
}

OF the vases figured on Pl. LXXXIII. nos. 1, 2, 4, and 5 come from the island of Calymnos. Nos. 1, 4, 5, and the large amphora of which a cut (Figs. 1,2) is given below, belong to a series which has been described by Cecil Smith in the Classical Review, i. p. 80 . The Bügelkanne (no. 2), was obtained by me subsequently, and was found on another site. The sponge-fishers of Calymnos have, by little and little in the last hundred years or so, come to regard the probability of invasion as more remote, and have consequently devoted their spare time and money to bringing their houses nearer the sea, until they have at length taken their lives in their hands and established themselves close to their native element. When Ross visited the island the only town was that which is still known as ' $\eta \dot{\eta} \chi^{\omega} \rho a$.' It is situated about two miles from the harbour and immediately underneath the still older medieval fortified town, now quite deserted. There is no evidence that there was an ancient city on this site, but the chief sanctuary of the island, the temple of Apollo, was in the immediate neighbourhood, on a ridge which overlooks two of the most productive valleys in this barren island. Most of the inhabitants have now moved down to the modern town which is close to the harbour and which bears the name of an ancient deme-Pothia. This name is probably genuine, as that tender regard for antiquity which finds a home for an outcast ancient name in the face of inseparable difficulties is not so developed here as in the kingdom of Greece. That there was a Hellenic settlement on this site is indicated by the inscriptions and 

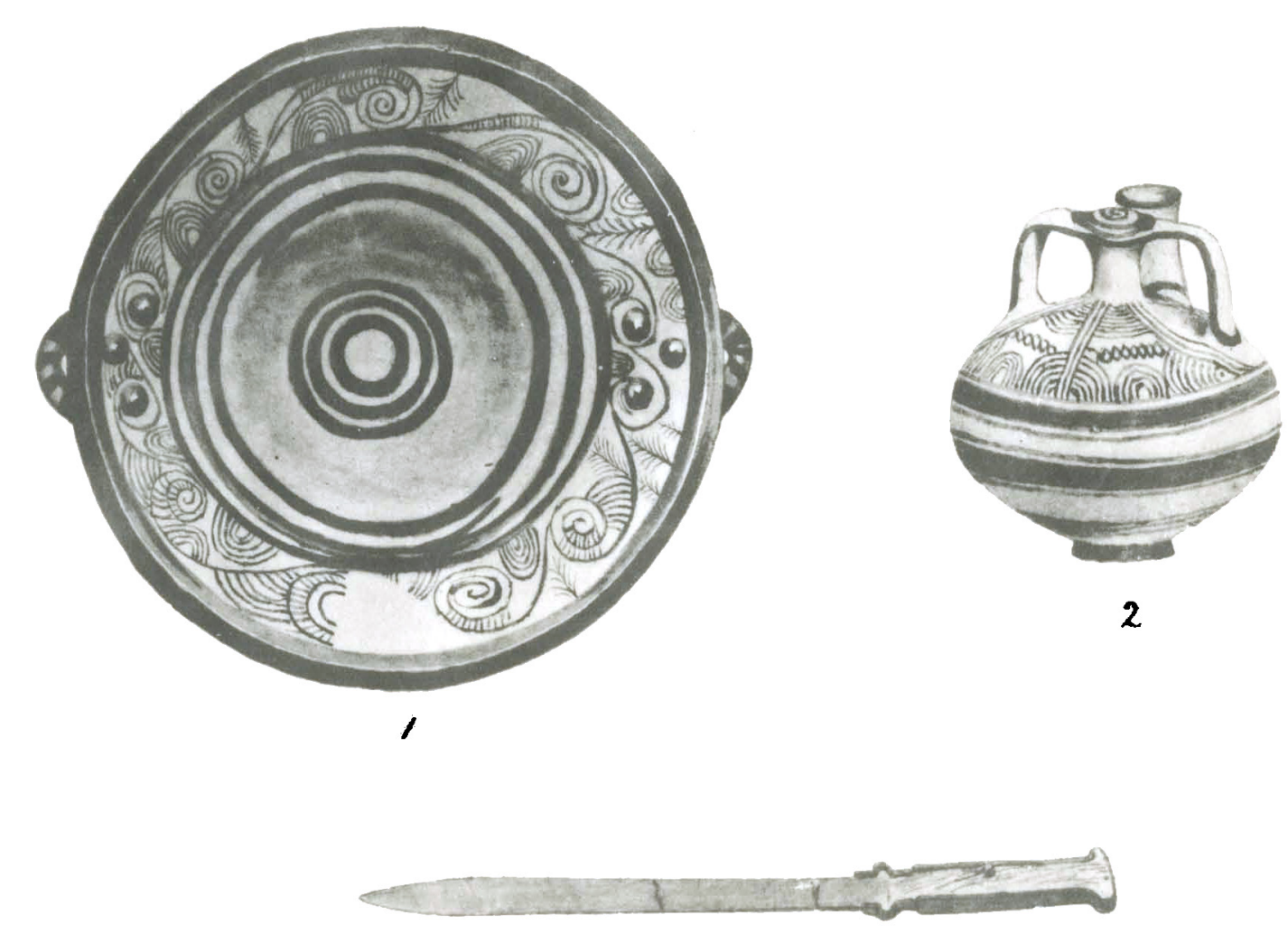

3
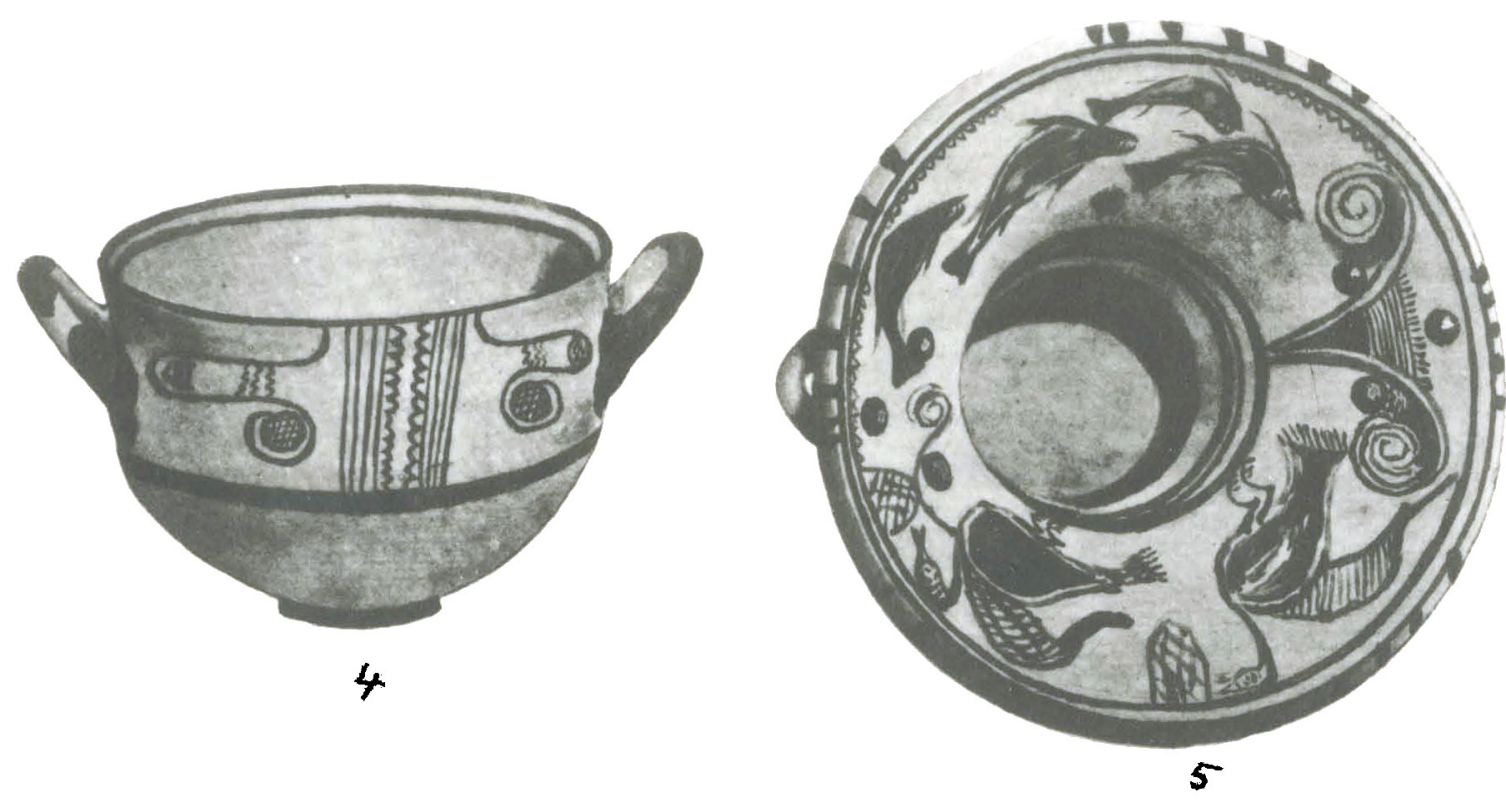

CALYMNA
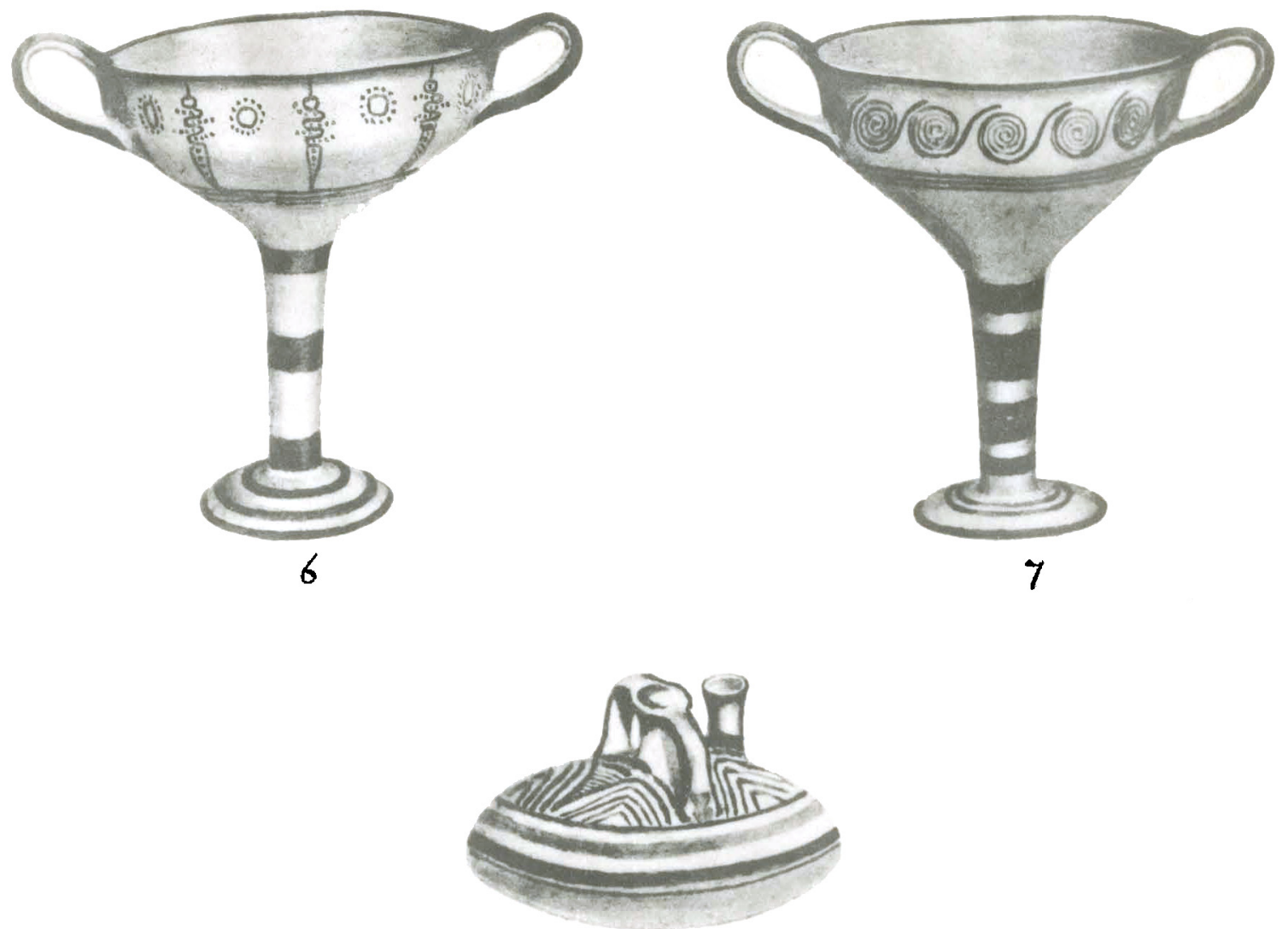

3

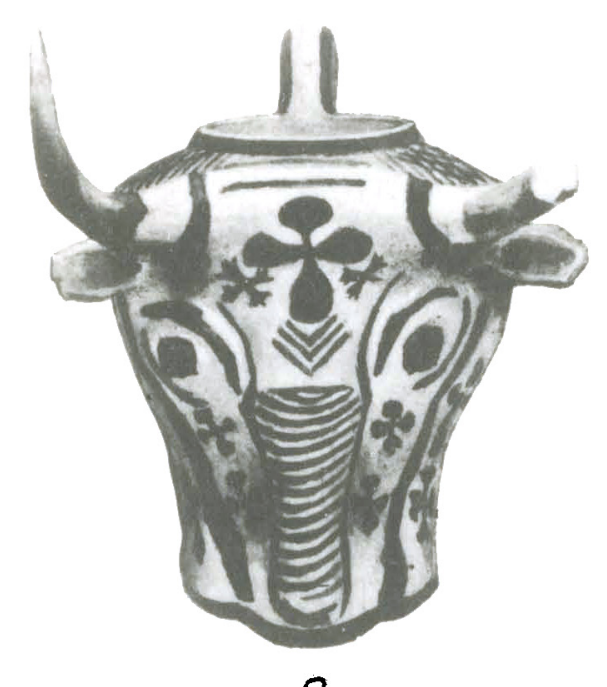

CARPATHOS

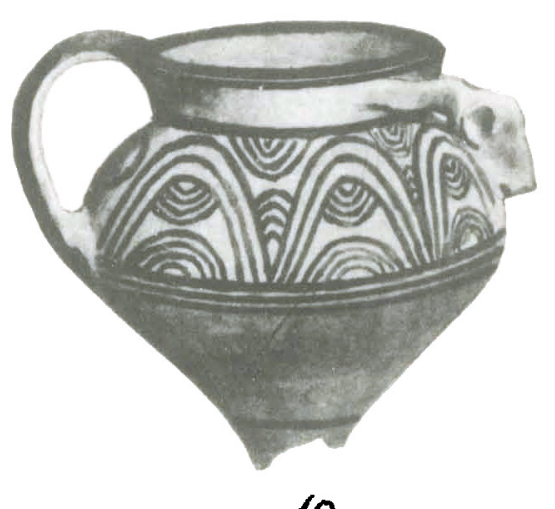

10 
fragments of architecture which have been found near the old church of the 'Panagia Calamiotissa' (not Calymniotissa as Newton gives it in the Inscriptions of the British Museum).

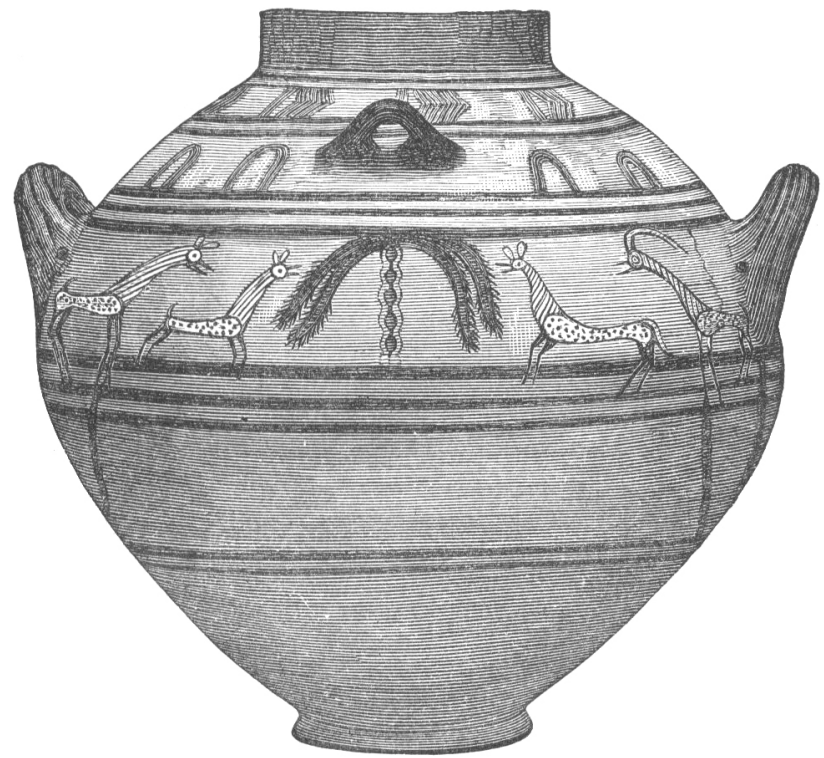

Fig. 1. Vase from Calymnos.

Quite near this modern town, on the slopes to the east of the torrent which falls into the harbour, there is an extensive Hellenic necropolis. The tombs which have given us these

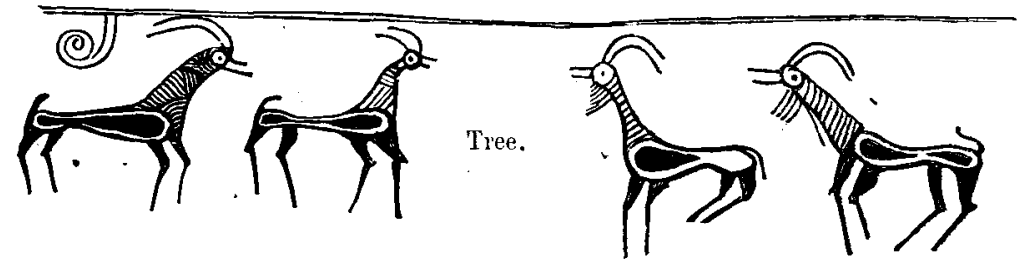

Fig, 2. Animals on reverse of vase.

vases are situated on the hill to the west of the torrent, and are excavated in the pumice (pozzolana). All I can learn of the circumstances of their discovery is that the twenty vases 
described in the Classical Review, i. p. 80, and about ten others of inferior interest, were found together. The Biigelkanne, (no. 2), was found with other Mycenaean vases, most of which were broken, on a site about half a mile distant, but also in the pozzolana on the right bank of the strean.

Although these vases are undoubtedly later than most of those from Ialysus, I do not think there is any reason for pronouncing them to be later than many of the fragments from Mycenae and Tiryns; and certainly none for calling them archaistic, as Reinach does in his notice of them, Rev. Arch. x. p. 83. The animals on the large vase (Fig. 1) seem to have been drawn by a hand accustomed to draw birds : cp. the heads and necks of the birds on the vase Myk. Thongef. pl. ix., and the bird's head Myk. Vasen, no. 400. Quadrupeds drawn in the same style appear on the fragments Myk. Vasen, nos. $409,412,416 a$ and $b, 417$. As birds occur on Mycenaean pottery before quadrupeds, this shows quite a natural development. We have no exact parallel from Mycenae for the manner in which the bodies of the animals are filled in with dots, but a glance at $M y k$. Vasen, nos. 392, 397, 398, 406, 417, and Tiryns, pl. 15 $\alpha$, will show that there is great latitude in the fillings which are adopted for the bodies of animals. We find them filled in with dots on a fragment from Tiryns (plate xxi.a), belonging to a class certainly later than the Calymnos vases, and distinguished by the use of white paint, and by subjection to the influence of the geometric style, The bodies of the fishes and birds on the calathus, (no. 5), are completely filled in in the colour of the glaze, like those of most of the quadrupeds on the fragments from Mycenae, where on the other hand we find on the bodies of fish and birds various combinations of lines (Myk. Thongef. pl. ix., Myk. Vasen, 383, 384, 397, 398, 402, 415 , and $63 b$ from Ialysos). The reverse of our vase (Fig. 2 ) is occupied by a similar scheme of two pairs of animals facing a tree. Their bodies are filled in with colour, but not entirely, a space being left between the filling and the outline. There is nothing else in the decoration of the vases which would warrant us in placing them in a category by themselves. The heraldic scheme of two animals facing a tree, which betrays oriental influence, is found at Mycenae (nos. 412, 413, and fig. 36). The shapes of the bird's tails on our no. 5 show an adherence to the older traditions of Mycenaean painting, as they correspond very closely 
to those on a vase from one of the tombs, Mylk. Thongef. pl. ix. ${ }^{1}$

The bronze sword (no. 3), and the five vases 6-10, are from Carpathos, and were found, according to trustworthy information, in the same tomb. They have been already described in Furtwängler and Löschke's Mykenische Vasen, p. 83. There are only two mistakes in this notice which I have to correct. The first relates to the discovery of the tomb, the credit of which is wrongly assigned to me; the second to the description of no. 10. This vase has not two handles, but opposite the handle the head of a goat is applied in relief. For an animal's head thus employed we may compare Myk. Vasen, pl. xliii. There it is underneath the handle. The form of the vase, if we except this appendage, exactly corresponds to no. 71 .

The bronze sword corresponds in form to Myk. Vasen, pl. D, no. 11. The handle had been filled with ivory, fragments of which were found still attached to the rivets.

Although several of the vases here published show interesting varieties of form and ornament, their importance lies rather in the locality of their discovery, than in the additions which they furnish to our knowledge of the Mycenaean style. The occurrence in an island so near the coast of Caria as Calymnos of an extensive Mycenaean necropolis might seem to favour the hypothesis of the Carian origin of this civilisation. I take this opportunity of making a few remarks on questions suggested by this discovery and by the results of excavations which I made in Caria in 1886.

Although much study continues to be devoted to the early pottery of Greece, the ethnographic relation of the Mycenaean and geometric styles has still to be establisbed. While we know the former to be the earlier, we have no evidence which enables us to assign a definite chronological limit to the period of either. The scarab of Amenhotep III. from Ialysos loses any value it ever possessed in this respect, if it is, as Torr pronounces (Classical Review, i. p. 250), a later imitation. I scarcely think that our knowledge or ignorance of Egyptian art in the interval

1 Furtwängler conjectures that the difference in the birds' tails on this vase is a distinction of sex. We certainly find this distinction in two other- wise similar animals on the reverse of our amphora (Fig. 2), one of which has a beard while the other has none. 
can be profound enough to enable us to assert with him, that an imitation of a work of the fifteenth century cannot have been made until the seventh, and in any case we could not take the pottery with us in this salto mortale, as nothing 'Mycenaean' is recorded as having been found in the same tomb with the scarab. The occurrence of a Bügelkanne on the wall-paintings of the tomb of Rameses III. only shows that this form was then known in Egypt or Phoenicia, from whence the 'Mycenaean' ceramic art may afterwards have borrowed it. The signed vase of Aristonophos, which is executed in the style of the most remarkable of those from Mycenae (Myk.Vasen, pl. 42 and 4:3), is evidently an imitation, probably of Italian origin ${ }^{1}$ (Arndt, Studien zur Vasenkunde, p. 4). Köhler (Mitth. iii. p. 8) was the first to assign a Carian origin to the 'Mycenaean' civilisation. Furtwängler and Löschke regard the 'Mycenaean' style as Achaean, the geometric style as Dorian, but as they print 'Achaean' in inverted commas and style the pottery preHellenic, it is evident that they do not assign to the term its strict ethnological meaning, and we must wait for the book on the subject which Furtwängler has promised us, to learn what it connotes to him. Jümmler and Studniczka (Mitth. xii. p. 1), have given convincing reasons for regarding the geometric style as proto-Hellenic, and the 'Mycenaean' style as foreign or pre-Hellenic. They both adopt Köhler's Carian hypothesis.

It is better if we can to look at the question first from the point of view of a palaeethnologist unaided and unencumbered by literary tradition. The tombs of Mycenae and Orchomenus, and the palace of Tiryns have revealed to us the art of a

1 I think the Italian origin of the vase is indicated by its subject. Another monument, which gives us also one of the earliest representations of Greek myths, in point of style, which we possess, the carved tusk from Chiusi (Mon. x. pl. xxxviiia) relates to the same story, that of Polyphernus ; a story localised in the West. That this carving is not Phoenician work is shown by the type of the griffin, which is Greek, and by the lotus pattern which resembles that on the Rhodian vases, but the style of the figures is Phoenician, and the tomb in which it was found must belong to the same period as the ReguliniGalassi tomb at Caere (cp. the pattern on the bronze fragment Mon. $\mathrm{x}$. pl. xxxviiia with Mus. Etr. pl. xxxii.), where many objects in metal and ivory were found which we know to be Phoenieian in style. Although these two works are executed under different influences, the identical form of the ships on both is a sion of common origin. 
people, who were evidently in close relations with Egypt. This Egyptian influence is most apparent in the wall decorations of Tiryns and Orchomenus, where we have designs borrowed from the tombs of Thebes (see Schliemann, Tiryns, p. 111), and in the contents of the probably contemporary necropolis of Ialysos. But even in the earlier tombs inside the wall of Mycenae we have not only a method of burial resembling the Egyptian, but we find bronze weapons of Egyptian shape, the inlaid work on which is certainly Egyptian in style if not in workmanship. In the pottery of the same epoch we have a system of ornament, independent in its origin of any known foreign influence, and obviously developed among a maritime people. This native system makes itself felt in the mural paintings, but does not borrow the more ambitious Egyptian designs of the latter. Although among the objects in metal and ivory found in the tombs there are some which may be regarded as Phoenician importations (e.g. the gold Astarte-figures from Mycenae, and the ivory box from Menidi), we find on the pottery the very slightest traces only of oriental influence. The motive of two animals facing a tree only occurs on the latest examples, and the tress, a favourite ornament in Mesopotamia, is found only twice (Myk. Vasen, 9, 338). We are led to look for the origin of this pottery in the islands of the Aegean partly by the marine ornaments, and partly because it can be shown to be derived from an earlier class of ware, found in the prehistoric settlements of 'Thera, and which is again connected with the earliest pottery of the 'Hissarlik' period (Dümmler, Mitth. xi. p. 32); Furtwängler has promised to demonstrate this. The area of its discovery extends over Eastern Greece, the Southern Cyclades, Crete, Rhodes, Cyprus, and the islands off the coast of Caria. In the northern islands of the Aegean very few specimens have come to light, and we have practically nothing from Asia Minor. In Cyprus the later classes of 'Mycenaean' ware begin to show themselves only in the later tombs of the epoch represented by the necropolis of Alambra. Phoenician vases make their appearance simultaneously (Dümmler, Mitth. xi. p. 234). It is evident that Cyprus is thus excluded from the area within which the style may have originated. The same remark applies to Melos for the same reason (Dümmler, Mitth. xi. p. 40). Indeed Thera is the only island where vases of the 
earliest Mycenaean technique have been found. We may, I think, conclude that the Mycenaean style had its origin among some family of the people whose remains we find at Hissarlik, in Cyprus and the Cyclades, at a time when these people were already in communication with Egypt and the East, and that the locality of its birth and growth is to be sought somewhere in the southern coasts or islands of the Aegean, but probably not in the Cyclades. The geographical distribution of the finds rather points to Crete as a centre of production, during the prevalence of the later styles at least, and Thera where the transitional vases have been found is, of all the islands, that most accessible from Crete. Certainly the lentoid gems which accompany this ckass of pottery have been found in greater numbers in Crete than elsewhere.

Although we are less perfectly instructed concerning the customs and surroundings of the people who employed the 'geometric' style, we know that it only appears in the seats of Mycenaean civilisation at a late period of the latter. We cannot I think say that it derives anything from the style which preceded it (except possibly the shape of the Bugelkänne). There are certain geometric motives, such as cross-hatching, triangles and rhomboids, which the Mycenaean style inherited from the 'Hissarlik' types of ornament, and which are also common to it and the later geometric style. On the other hand the maeander is foreign to it, and concentric circles are only employed to accentuate the shape of the vase. Furtwängler and Löschke cite the quatrefoil and the double axe among the types borrowed by the geometric style, but the quatrefoil on 'Mycenaean' vases, such as the bull's head (pl. lxxxiii. fig. 9), is perfectly different from the 'geometric' form (see Annali, 1872, pl. $\mathrm{k}$, no. 8). The double axe on the 'Dipylon' vase (Cesnoic Cyprus, pl. xxix.) has the form which we know from Cariau coins and monuments. That on the fragment, Myk. Vasen, 195, is something quite dissimilar, and I question whether it is an axe at all, as the same object occurs on other 'Mycenaean' vases without any trace of a handle.

The geometric vases are found associated with fibulae, iron weapons (Helbig, Homer. Epos, 2nd ed. p. 79 ; Monuments Grecs. 11-13, p. 42), and incineration, while in the 'Mycenaean' tombs the weapons are of bronze and burial is practised. We have in 
fact an absolute break in our tradition, which can only be accounted for on the hypothesis of conquest by a different race. The earlier style however survived after the introduction of the later, and gradually came under its influence. This influence is especially apparent on fragments from Tiryns (see F, and L. Myk. Vasen. p. xii.) Everything points to the conclusion that the conquerors were Greeks, and the conquered race therefore not Greek. With the geometric style begins the organic development of Greek pottery; we can trace its influence through a certain class of vases found chiefly near Athens and illustrated by Böhlau (Jahrbuch, 1887, p. 33) until we come to the earliest inscribed Attic vases (Beundorf, Griech. Vasenbilder, pl. liv.). The form of these transitional vases and the style of the figures are quite 'geometric.' Whatever 'Mycenaean' elements we find in them are probably derived from the islands, where this influence seems to have remained active; the small ornaments scattered on the Melian vases and the spirals are undoubtedly 'Mycenaean.' We have other specimens of this mixed insular style in the fragment of a pithos from Crete (Mittri. 1886, pl. iv.), and on gold work found at Corinth (A.Z. 1884, pl. 8). This vitality of 'Mycenaean' traditions in the islands seems again to point to the conclusion that the style originated there. The Greek character of the 'geometric' style is confirmed, as Studniczka has shown, by its association with the fibula, and by its long continued ceremonial and sepulchral use in Attica and elsewhere.

Further researches may enable us by the aid of this clue to trace something of the earlier history of the Greek race, and to determine the degree of their kinship with other peoples. For the purpose of a comparison of geometric pottery from Greece with that found elsewhere, we may, in the absence of a history of its development, distinguish two classes: (1) Vases of the 'Dipylon' type proper, where figure-paintings are common, and where there is a predilection for small concentric circles connected by tangents; (2) Vases where the decoration is purely geometrical and is composed chiefly of horizontal bands, maeanders, large concentric circles, and zigzags. The bodies of these latter are usually glazed, only a small field being left for the ornament. Pottery ornamented in this simple geometrical manner is found in Greece, in Rhodes (Camirus, see Jahrbuch, 
1886, pp. 136-7), and in the tombs of Assarlik in Caria (supra, p. 64). The cinerary amphora from thence (p. 71, fig. 8) exactly corresponds in form and ornament to amphorae from Greece in the British Museum; the only apparent difference is that some of the encircling bands are filled in with white colour. I do not know to what extent white can be detected on geometric vases from Greece; at any rate it has disappeared, if it ever existed, on the specimens I have seen. I am inclined to regard it as a mark of Asiatic origin (v. infra). The concentric halfcircles on the Buigelkanne from Assarlik (fig. 18) and on the small amphora (fig. 6) may be compared with those on the Rhodian vase (Jahrbuch, 1886, p. 136, no. 2996). The vase from the 'tomba del guerriero' at Corneto (Mon. x. pl. x. $c$, no. 12) belongs to this class, and its similarity to pottery from Camirus has been pointed out by Helbig (Ann. 1874, p. 262). At Assarlik were found fragments of vessels where the ornamentation is more limited, consisting only of horizontal bands and large concentric circles, and where the body of the vase is not glazed (see p. 72, fig. 15). It is however impossible to draw a definite line between these vases and those where glaze is more extensively applied, as the same decorative motives are found on both, and the surface of the pottery has been so much destroyed, that we cannot tell in many instances where there has been glaze and where not. Fragments bearing a close analogy to the Assarlik pottery have been found by Dennis in the Bin Tepe tumuli at Sardis (Smith, Class. Rev. i. p. 82), and by Spiegelthal in the tomb of Alyattes there. The latter have been described and illustrated by Olfers (Lydische Königsgräler bei Sardes, pl. v): in three instances, figs. 4, 5, and 6 white colour is employed. The vase figured in the Annali, 1872, pl. $\mathrm{K} \mathrm{13}$, seems to belong to the same class, and is thus described by Hirschfeld, p. 153: 'In clay, form, and colour, it is quite different from the vases together with which it was found. The clay is of an opaque red, and is covered with glaze of a blackish hue, in which, on the body and rim, are incised straight lines filled with white. It is with some hesitation that I cite for comparison with this vase some others found in the socalled tomb of Alyattes in Lydia, as it has not been possible to find this pottery at Berlin.' 'The vases mentioned in the text are those described by Olfers, those referred to in a fuot- 
note as having a similar glaze are no doubt Dennis' fragments. It is unfortunately impossible to decide if the exact technique here described is employed on the Assarlik vases, as the only one which showed traces of white lines has been injured in cleaning. Probably the fragment found near the tomb of Tantalus at Old Smyrna mentioned by Burgon (Tr. R. S. of Lit., N. S. ii. p. 258) is also to be added to this list. $\mathrm{He}$ cites it as resembling Athenian geometric pottery. It is impossible to judge from the illustration which he gives. Professor Ramsay has shown me fragments decidedly of the same class as those from Assarlik, which he picked up in the neighbourhood of Phrygian tombs.

I think that, as this ware only occurs near centres of Greek colonisation, we cannot help recognising here a geometric style of Asiatic origin, to which the majority of the Rhodian vases and some of those found in Greece and even Italy belong; and, as fibulae and gold ornaments such as those from Assarlik are elsewhere associated with geometric ornament and incineration, we cannot separate them from the rest of the find, and must expect to discover them also in the Asiatic tombs which contain similar pottery. Whether such tombs are peculiar to the west of Asia Minor, or extend far inland, we do not as yet know.

Supposing the existence of an Asiatic geometric style to be established, it does not follow that that of Greece is derived from it. It may be possible to distinguish a Greek style characterised by the employment of the small concentric circles connected by tangents, which we find on bronze work of undoubtedly Greek origin, and an Asiatic style to which large concentric circles and possibly the use of white ${ }^{1}$ are peculiar. Could we be certain that the sarcophagi from Assarlik were Asiatic, we should have to admit a much more direct and powerful influence of Asiatic on Greek work than the evidence of the painted vases enables us to detect. The stamped designs upon them correspond very closely to painted ornaments on fragments from Tiryns and Athens. (Tiryns, fig. 21, pl. xvia. pl. $\mathrm{xx} b$. Mon. ix. pl. xxxix., and for the fringe outside the circles on fig. 24, p. 77, cp. Tiryns, pl. $\mathrm{xx}$ a.). But it is possible

1 For the characteristic use of white on later Asiatic pottery, see Smith, J.H.S. vi. p. 185. 
that these sarcophagi may be imported. It is interesting to find that M. Rayet was inclined to regard the geometric style as of Carian origin (Mon. Grecs, nos. 11-13, p. 43). I am sorry to say that, if the book mentioned there has been published since his lamented death, I have not seen it.

In Italy during a period when the weapons are chiefly of bronze and when iron is of rare occurrence, we find fibulae and incineration together with incised geometrical patterns on the pottery (Poggio Renzo, Villanova, the majority of the 'tombe a pozzo' at Corneto). As the 'geometric' discoveries in Greece and Asia belong to the developed iron age, we have no materials for comparing this system of ornament with that employed by those people in the same stage of civilisation, but it resembles that of the later Greek painted geometric pottery in its love for the maeander and differs from it in its avoidance of circles. This absence of circles may indeed depend only on technical reasons, as they would not be attempted by a workman tracing patterns in moist clay with the hand: indeed it seems that stemped circles do occur on certain vases from these tombs. (Helbig, Ann. 1884, p. 131.) With the introduction of the precious metals, the more general use of iron and traces of communication with Egypt, burial begins to take the place of burning. Among the articles of personal ornament most frequently found in the later 'tombe a pozzo,' where the bodies are still burnt, are circles of pale gold attached to bronze, (Mon. xi. pl. xxiva. 6, pl. lix. 23, Mon. xii. pl. iii. 21. Bull. 188:, pp. $43,163,213,1883$, pp. 115, 120), and spirals of either bronze, silver or gold, which Helbig conjectures may be for the hair (Homer. Epos. second edition, p. 243). Two similar spirals were found in one of the Assarlik tombs (supra. p. 69, fig. 7); of the pale-gold circles we have one specimen from Assarlik (fig. 11), and three from Rhodes, A.Z. 1884, pl. 9, nos. 6 and 8 (Camirus!, Myl. Vasen, p. 17, fig. 5 (Ialysus). In a few of the later 'tombe a pozzo,' and in the 'tomba del guerriero' (Mon.x. pl.x.). and others of its class (Bull. 1874, p. 55), where burial is practised, but which are connected with the earlier tombs by the occurrence in them of semilunar razors and other objects, we meet for the first time with painted pottery. One of the vases from the 'tomba del guerriero' is, as we have seen, probably Asiatic, but the others show a different system of 
ornament. There are no circles, but, together with common geometrical patterns such as broken maeanders, rhomboids, and triangles, we have friezes of birds. These birds occur on the geometric fragments from Nineveh (Ann. 1875, pl. H.), and they seem to be the earliest and commonest animal motive employed by the Greek 'geometric' style. Gold ornaments with similar designs were found in the same tomb, Mon. x. pl. xb. 2, cp. A.Z. 1884, pl. 10, 1. As these designs on gold and pottery appear at a period not distant from the introduction of the precious metals and of the art of painting on clay, we are justified in concluding that the system of decoration here employed was imported simultaneously. We cannot connect it directly with Greece or Asia Minor, but the pale-gold circles and the spirals, as well as the occurrence of the Asiatic vase mentioned above, indicate at least communication between Asia Minor and Etruria.

We may now inquire how the facts we have met with illustrate and are illustrated by information derived from other sources and current hypotheses.

In the early native Italian tombs we have indications of affinity with the Greeks and some justification for referring the geometric style to an Italo-Greek or Aryan origin, while in the contents of the first tombs where there are traces of foreign influence there is at least fuel to feed a belief in the Asiatic origin of the Etruscans. We are fortunate in being able to look forward to a comprehensive treatment of these questions by Helbig in the second part of his 'Beiträge zur altitalischen Kultur- und Kunst-Geschichte.'

The existence in Greece and Asia Minor of allied geometric styles, combined with fibulae and incineration, will, if confirmed, point here also to a common origin of their populations. If we had to deal only with the Leleges, to whom the tumuli of Assarlik and old Smyrna probably belong, we might point to many parts of Greece where Leleges are said to have once existed, and to names ending in -ssos, -ssa, -sos, -sa, which meet us frequently in Greece, and which, although distributed over a large aren in Asia Minor, are far commonest in that part of the sea-coast of Asia which was the home of the Leleges (see Pauli, Vorgriechische Inschrift auf Lemnos, p. 44). If, however, these discoveries extend over Phrygia and Lydia, our conclusions 
will reach further, but we must wait before formulating them for clearer notions of the ethnography of Asia Minor.

If we regard the non-Hellenic character of the Mycenaean civilisation as established, we must reconcile this with its correspondence in many particulars and in geographical distribution to the Greek world of epic tradition. Its most important seats are at Mycenae, Orchomenus, Sparta, the towns most famous in the Epos. The relations in which the 'Mycenaean' people stand with regard to Egypt are mirrored in the account of the voyage of Menelaus and the narrative of Odysseus (Od. $\xi$ 192). The conspicuous position occupied by Crete in the Homeric poems accords with the conjecture that it was one of the chief seats, and probably the fatherland, of this civilisation. It might perhaps seem too adventurous to seek in the Mycenaean vases found in Sicily (Ann. 1876, p. 56), an illustration of the early connection between Crete and Sicily shadowed in the stories of Daedalus and Minos. The area of the distribution of Mycenaean pottery in the Mediterranean seems curiously conterminous with that described as Greek in the Homeric catalogue, and which was subsequently Dorian. If, starting from the Peloponnesus, we travel through the islands where extensive Mycenaean discoveries have been made, Aegina, Melos, Thera, Crete, Rhodes, Carpathos, Calymnos, we are accompanied by Homer and the Dorians, and where one guide fails us, as in Thera and Melos, the other continues. On the other haud, we have much to set off against this correspondence with Homerie tradition. Helbig has shown in detail how the Greeks of the Epos had degenerated in the arts of war and peace from the princes of Mycenae. The descriptions of the entombments of Hector and Patroclus suggest to us, as Studniczka has already noticed, a form of burial, as well as a structure of tomb, such as we find at Assarlik together with 'geometric' surroundings. ${ }^{1}$ We can only arrive at the conclusion that the 'Achaean' conquerors of Sparta and Mycenae found there a people whose civilisation they inherited rather in the imagination of the epic poets than in reality; that, after reaching the heart of this civilisation in the Peloponnesus, or possibly in Crete, they

1 Even the envelopment of the cineillustrated by a discovery at Corneto rary urn in a linen cloth has been

(Bull. 1884, p. 13). 
circulated with it through the islands, and that the Dorian colonisation, if not identical with this progress, at least, starting from the same source, followed in the same track. Wherever we seek the birth-place of this Mycenaean civilization, certainly there is no evidence of weight for its Carian origin. We should in that case expect to find survivals of it in Caria after it had disappeared even from the islands. Nothing 'Mycenaean' has been found in Caria and the pottery of the Leleges, the inhabitants of its coast, belongs, as we have seen, to a primitive geometric system. The Carian or Lelegian ownership of the tombs of Assarlik, which I have assumed throughout, has been questioned by Studniczka (Mitth. xii. p. 18). I have tried to show that Assarlik is the site of Termera, a town of the Leleges, but the strongest argument is of course the Asiatic character of the pottery. If Helbig is right in his interpretation of the line, Il. B. 872, referring to Amphimiachos the leader of the Carians, we have in the spirals found at Assarlik at least an interesting illustration of it. We cannot argue from the occurrence of the double axe either on the ring from Mycenae, or on the Dipylon vase (Cesuola, Cypmus, pl. xxix.) for the Carian origin of either, and, if we could, the latter corresponds most closely to the Carian form. The double-axe was probably not originally any more exclusively Carian than the triquetra was exclusively Lycian. The tradition preserved by Plutarch (Quaest. Graec. 45) seems to indicate that it was derived from Lydia. We have, it is true, notices of Carian settlements in Greece, but not in those places where products of Mycenaean art have as yet been found. I think that the whole story of the Carian occupation of the islands is lacking in trustworthiness. As Herodotus tells us, the Carians themselves knew nothing of it. It is a little curious that this historian should go to the Cretans for the early history of his native land, even supposing a well-known saying had not reached his ears. Most probably he did not hear this story in Crete, but in Halicarnassus, where it may well have originated in the time of Artemisia, whose mother was a Cretan lady. It seems to be formulated in a way calculated not to wound the susceptibilities of the native population of Caria. Thucydides derives his information from Herodotus, adding as a confirmation the tombs found in Delos. Probably these were Greek tombs of the 'geometric' period in which the bodies were 
burnt, and a quantity of iron weapons were deposited. At the date of these interments the method of disposal of the dead and the shape of the weapons were doubtless similar in Caria and Greece. Here they had been superseded in Thucydides' time, but had survived in Caria, until this day, of all the coastprovinces of Asia Minor, that most impervious to Hellenic influence.

W. R. Paton. 